\title{
THE ENGLISH STATUTE OF FRAUDS IN NORTH CAROLINA: A STATUTE SPURNED
}

HE STATUTE 29 Car. II, c. 3 (I677), commonly known as the
Statute of Frauds, undoubtedly is one of the most important English statutes ever passed. ${ }^{1}$ Although its provisions relating to formalities in the execution of wills ${ }^{2}$ have generally been separately reenacted, subject to modification, in codifications of the law of wills, ${ }^{3}$ the Statute has not thereby lost its position of preeminence: constantly reappearing learned disputations as to its history ${ }^{4}$ and purposes, ${ }^{5}$ as well as exhaustive treatises, ${ }^{6}$ bear witness to its continuing, if not expanding, ${ }^{7}$ impor-

${ }^{1}$ See 6 Holdsworth, History of ENGLish LaW 379 (1927); and especially Hazeltine's foreword to Williams, The Statute of Frauds, Section Four (1932).

2 29 Car. II, c. $3, \$ \S 5,6,19,20,22,23$ (1677).

${ }^{3}$ See generally Bordwell, The Statute Law of Wills, 14 IowA L. REv. 1, 8, 26 ; 283 (1928-29); AtKinson, Wills cc. 7, 8, ro (2d ed. 1953). Adoption and adaptation by North Carolina of specific provisions of the Statute with respect to wills is discussed infra at notes 34 and 35 .

' Costigan, The Date and Authorship of the Statute of Frauds, 26 HARv. L. REv. 329 ( 1913$)$; Hening, The Original Drafts of the Statute of Frauds (2, Car. II, C. 3) and Their Authors, 61 U. PA. L. REv. 283 (1913); HoLDswORTH, supra note 1; Rabel, The Statute of Frauds and Comparative Legal History, 63 L.Q. REv. 174 (1947).

"There are those who think that it is a statute for the prevention of frauds and those who think that it is a statute for the perpetration of frauds. Between them are those who think that its purpose is to provide for additional litigation and thus increase the income of the legal profession. Lord Chancellor Nottingham is reported to have said that "every line of [the Statute] was worth a subsidy;" see HoLDsworth, op. cit. supra note 1 , at 384 n. $2 ; 4$ CAMpbell, Lives of the Lords Chancellors $278 \mathrm{n}$. c ( 5 th ed. 1903). In view of the fact that Nottingham regarded himself (justly) as the father of the Statute [see Ash v. Abdy, 3 Stwans. $66_{4}$ (app.), 36 Eng. Rep. 1or $\left.4\left(\mathrm{r}_{678}\right)\right]$, this does not seem to be a particularly modest claim. Lord Brougham, in his famous "Present State of the Law" speech of February 7, 1828, expressed himself as in accord with Nottingham's evaluation and indicated that he favored the addition of a few lines to the Statute. Brougham, PResent State of THE LAW 104 (1828). Edward Sugden is reported to have answered caustically that every line was worth a subsidy "to the lawyers . . . for there was not a line of it which had not cost a subsidy to the country." 2 Atrax, The Victorian Chancellors 11 (1908). The latter view seems to be in the ascendancy: the English Law Reform (Enforcement of Contracts) Act, $2 \& 3$ Eliz. II, c. 34 (1954) repealed most of what was left of the Statute, with the exception of the guarantee provisions of section 4. Sce Notes, 67 Harv. L. REv. 383 (1954); r7 Modern L. REv. 45 (1954). The verdict of Dean Stevens, Ethics and the Statute of Frauds, 37 CORNELL L.Q. 355 (1952), also seems to be basically adverse to the Statute.

${ }^{\circ}$ See, e.g., 2 Corbin, Contracts (1950); Benjamin, Sales, part II (8th ed. 
tance. Yet, surprisingly, important provisions of the Statute are not presently in force in North Carolina, ${ }^{8}$ and it has been believed for a long time that the English statute was never received or reenacted into the law of the colony or state. An attempt will be made here to present the history of this English statute as it affects the law of North Carolina. ${ }^{\circ}$

\section{The Colonial Period}

The first charter granted by King Charles II to the Lords Proprietors of Carolina on March I5, I663, gave them full and absolute power

for the good and happy government of the said province, to ordain, make, enact and under their seals to publish any laws whatsoever ... of and with the advice, assent and approbation of the freemen of the said province, or of the greater part of them, or of their deputies....

1950); I Williston, Sales c. 3 (revised ed. 1948).

${ }^{7}$ See, e.g., Browne, Statute of Frauds, Ist ed. 1857,556 pages; $2 \mathrm{~d}$ ed. 1863 , 566 pages; 3 d ed. 1870,565 pages; 4 th ed. 1880,671 pages; 5 th ed. 1895,687 pages. The last edition commences with the observation that $I, 900$ cases decided since 1880 necessitated a careful revision of the text. Id. at i (5th ed. 1895).

${ }^{8}$ The most notable omission is section 7 , requiring evidence in writing for trusts in land. See Thompson v. Davis, 223 N. C. 792, 794-95, 28 S.E.2d 556, 557-58 (1944) and cases there cited; see also Lord and Van Hecke, Parol Trusts in North Carolina, 8 N.C.L. REv. I 52 (1930); and I BogerT, TRUSTS AND Trustees $\S 64$, at $386-88$ (195I). Nor is the sale of goods section in force. Odom v. Clark, 146 N. C. 544, 55 I, 60 S.E.2d 513, 515; cf. Hulburt v. Simpson, 25 N. C. 233 (1842).

${ }^{\circ} \mathrm{A}$ history of the Statute of Frauds in North Carolina, on the basis of reported decisions alone, would be quite brief. In Foy v. Foy, 3 N. C. I3I (Super. Ct. I80I), Judge Taylor is reported to have decided that "our law is the same as in England before [the Statute of Frauds]." In Gwyn v. Wellborn, I 8 N. C. 3I3, 3 I8 (I835), Gaston, J., stated that "in the year I 8 I 5 we had no statute of frauds." In Smithdeal v. Smith, 64 N.C. 52 (1870), Pearson, C.J., discussed the Statute of Frauds so as to give the impressiou that he thought it to be in force in North Carolina. In Odom v. Clark, I 46 N.C. $544,550,60$ S.E. 5 I3, 5 I 5 (1908), Hoke, J, declared that the Statute was adopted in toto by the Act of 1749 , but that "it has not been in force here since 1792, except to the extent that its different provisions have been expressly reenacted." In Thompson v. Davis, 223 N.C. $792,794,28$ S.E.2d 556, 557 (I944), Seawell, J., said that "the seventh section of the English Statute of Frauds . . . has not been enacted in North Carolina." The primary purpose of this comment is rather to present a case study of the reception of English statute law in the United States. See generally i Crosskey, Politics and the Constitution in the History of the United States 563-609 (1953), reviewed adversely by Goebel, Ex Parte Clio, 54 Colum. L. Rev. 450 (1954), in turn reviewed adversely by Petro, Crosskey and the Constitution: $A$ Reply to Goebel, 53 Mrch. L. REv. 312 (1954). Another purpose is to make a modest contribution to the study of colonial statutes, so magnificently pioneered by Riesenfeld, Law-Making and Legislative Precedent in American Legal History, 33 MinN. L. Rev. 103 (1949). 
Provided, nevertheless, that the said laws be consonant to reason, and as near as may be conveniently, agreeable to the laws and customs of this our kingdom of England. ${ }^{10}$

The second Charter, dated June 30, 1665, contained substantially identical provisions. ${ }^{11}$ It was only in the beginning of the next century, however, that the colony became sufficiently settled ${ }^{12}$ to require the establishment of a legal system of its own and the enactment of local statutes. ${ }^{13}$ In I7IO, the Proprietors appointed a governor of North Carolina ${ }^{14}$ and in March, I $7 \mathrm{II}$, the latter convened his first legislature which, among other things, passed an "Act for the better and more effectual preserving of the Queen's peace, and the establishing a good and lasting foundation of Government in North Carolina."15 Section III

10 I Colonial Records of North Carolina [hereinafter, with State Records up to 1790 , cited as N.C.C.R.] $20,23-24$ (1886).

${ }^{11} \mathrm{ld}$. at 102, 104-6.

${ }^{12}$ See Lefler and NeWsome, North Carolina 50, 600 (1954).

${ }^{23}$ As late as 1708 , it was said that "the Law here [i.e., Carolina] is a strange sort of Proteus capable of putting on all shapes and figures as occasion requires." Letter of Thomas Nairne, dated July 28, 1708, probably written to the Earl of Sunderland, reprinted in Calendar of State Papers, Colonial Series, america \& West indies, 1708-1 709 433-35 (Headlam ed. 1922). This statement specifically referred to what is now South Carolina, but at that time Carolina was still one colony, at least legally speaking. See Wallace, South Carolina-A Short History 77-78 (1951).

${ }^{14}$ Lffiler and Newsome, North Carolina 55 (1954).

${ }^{15}$ L. I7II, c. I; 25 N.C.C.R. $152-53$ (1906). The opening phrase of Section II, "whereas this Province is annexed to and declared to be a member of the Crown of England," is copied from a bill introduced in the House of Lords in 1701 which purported to revoke all proprietary charters and transform all overseas possessions into Crown Colonies and naturally was not enacted. A copy was sent to Carolina and read to the Legislature as an "Act." I N.C.C.R. 539-40 (1886); 25 N.C.C.R. 149-50 (1906). The reception statute itself was reenacted in L. 1715, c. XXXI, §§ 5-7. For a long time, a handwritten copy of the 1715 statutes was the only source of early North Carolina legislation. See I Revised Statutes of the State of North Carolins [hereinafter R.S.] vii (1837); Clark, Prefatory Notes, 23 N.C.C.R. (n.p. 1904/5). Consequently, subsequent revisals have generally cited the reception statute as 1715 , c. XXXI. See A Collection of All the Public Acts of Assembly of the Province of North Carolina: Now in Force [hereinafter SWANn's Revisal] 12 (1752); A Complete Revisal of all acts of Assembly of the Province of North Carolina Now in Force and Use [hereinafter Davis' Revisal] 6 (i773); Irdedell, Laws of the State of North CaRolina [hereinafter IREdell] I7 (1791); I MaRtin, The Public acts of the General Assembly of North-Carolina [hereinafter Martin's Revisal] ${ }_{3}$ (1804). Then, since I PotTer, Taylor \& Yancey, Laws of The State of North Carolina [hereinafter PotTer's Revisal] 102 (1821), the reception statute has been cited as I7I5, c. $5, \S \S 2$ and 3. See N.C. GEN, STAT. [hereinafter G.S.] $\$$ 4-I (1953), the present reception clause. The reason for this latter divergence seems to be nothing more than the arbitrary assignment, by PorTER's REVISAL, of new chapter headings to all colonial statutes then deemed relevant. There is 
of this act stated that "the common law is and shall be in force in this Government;" and Section IV reenacted "all statute Laws of England" made, among other things, "for preventing immorality and frauds."

At least by modern canons of construction, there is little doubt that the latter term would include the Statute 29 Car. II, the opening clause of which reads, "FOR prevention of many fraudulent practices, which are commonly endeavored to be upheld by perjury, be it enacted," \&c. However, the application of present methods of construction to acts of a legislature sitting more than two centuries ago would not seem to be a satisfactory method of establishing that the Act of I7 I I reenacted the Statute of Frauds by reference. Unfortunately, corroborative materials are somewhat sparse, but two factors suggest that the legislature did indeed intend to reenact the Statute, or that it was later felt that this had been done. One is that in I7I2, the legislature of South Carolina reenacted a long list of English statutes, ${ }^{16}$ among which was the Statute of Frauds. ${ }^{17}$ While this reenactment, of course, did not purport to apply to North Carolina, $^{18}$ it nevertheless indicates that it was felt at that time that there was no fundamental incompatibility between the Statute and the rather primitive state of the colonies-that, quite to the contrary, the reenactment of the Statute was considered to be desirable. The other factor tending to corroborate the construction that the Act of I7 I I reenacted the Statute of Frauds is that an abstract of North Carolina wills filed until $1760^{19}$ indicates that most (but not all) wills devising interests in real property were witnessed by three persons, as required by the Statute of Frauds. ${ }^{20}$

No great changes occurred in the private law of North Carolina when the Crown bought out the Proprietors in I729. ${ }^{21}$ However, twenty years later, the persistent complaints of the Governor about the now almost incomprehensible state of the laws of the colony ${ }^{22}$

no doubt now, however, that the reception statute was originally passed in $171 x$, not 17 5. See Battle, History of the Supreme Court, 103 N.C. 339, 345 (1888).

${ }^{20}$ Grimke, The Public Laws of the State of South-Carolina 25 (1790).

${ }^{17} \mathrm{Id}$. at 82 .

${ }^{28}$ Section 4 of the South Carolina reception statute provides that it applies only to "that part of this province that lies South and West of Cape Fear." Id. at 99.

19 Grimes, Abstract of North Carolina Wills (igio).

${ }^{20} 29$ :Car. Ir, c. $3, \S 5$ : “. . . all devises and hequests of any lands . . shall be in writing . . and shall be attested and subscribed . . by three or four credible witnesses. ..."

${ }^{21}$ See the instructions given to George Burrington, the first Royal Governor of North Carolina, 3 N.C.C.R. 90 (1886).

${ }^{22}$ Until the first printing of SwANN's Revisal in $175 \mathrm{I}$, all copies of North Carolina laws were handwritten. The 1749 Journal of the House of Burgesses was the first book printed in the colony. See facsimile thereof, vii-xv (State Department of Archives and History, Raleigh, 1949). See also note 23 infra. 
brought about a revisal of North Carolina legislation, completed in $1749{ }^{23}$ One of the most important products of this revisal was L. 1749 , c. $x$, which specifically reenacted the Statute of Frauds ${ }^{24}$ along with a vast number of other English statutes. Unfortunately, however, the same statute also assiduously avoided mention of any acts pertaining to the royal revenue and shrewdly provided that all English statutes not therein mentioned were not to be in force in the colony. For this reason, it was disallowed in toto by the King in Council on April 8, $1754 .{ }^{25}$ It is rather difficult to ascertain where this left the Statute of Frauds. However, when it is borne in mind that the enumeration of several statutes in the Act of 1749 must have been purely declaratory, ${ }^{20}$ this positive evidence of lack of hostility toward the Statute seems all the more to corroborate the theory that it was at that time regarded to be in force by virtue of the Act of I7II. Accordingly, it would seem to be safe to assume that the English Statute of Frauds was in force in North Carolina from $x 7 x \mathrm{I}$ on, or at least from $x 749$ on. At any rate, it must have been regarded as being in force between 1749 and 1754, when the act of 1749 was disallowed.

\section{Statehood}

Four days after the adoption of the Constitution of 1776 , the Halifax Convention, considering it "absolutely necessary for the safety and gaod government of this State that Laws be immediately in force here," ordained that "all such Statutes and such parts of the Common Law and Acts of Assembly heretofore in use here" and not contrary to the freedom and independence of the State were to be in force until the next session of the Assembly and no longer. ${ }^{27}$ It was apparently felt that the Declaration of Independence had, without more, worked a repealer of all law formerly in force; ${ }^{28}$ and an attempt was made by the same

${ }^{23}$ SWANN's Revisal, popularly known in North Carolina as the "Yellow Jacket." See I MoRdecai, LAW Lectures 6 (2d ed. Igi6). See also Governor Johnston's prorogation message of October 18, I 749, 4 N.C.C.R. roog (1886)."

${ }^{24}$ SWANN'S REVISAL 293-99; 23 N.C.C.R. 317-2.4 (x904).

${ }_{25} 5$ N.C.C.R. $8 \pi$, 106, 116, $117-18$ ( 1887 ).

${ }^{26}$ Compare the list of English statutes reported to be in force in I PoTTER's REvXsAL 85-96 ( 1821 ) with those listed in the Act of 1749 , note 24 stpra. No specific statute for the reception of English Acts of Parliament was passed between 1749 and $182 x$. The Statute of Charitable Uses, 43 Eliz. c. 4 (1601), e.g., is listed in both. It was remodelled by L. $1832-3$, c. 14, and is now contained in G.S. $\S \S 36-19$ to $36-$ 23.I (Cum. Supp. I953). For a square holding that the Statute 43 Eliz. c. 4 (1601) was in force in North Carolina before the Act of $1832-3$, see Griffin v. Graham, 8 N. C. $96,1_{32-3}(1820)$. In some other states, this question was very much in doubt for a long time. 2 BOGERT, TRUSTS AND TRUSTEES $\$ 322$, at I925-30 (1939).

${ }_{28}{ }_{23}$ N.C.C.R. 992 ( 1904$)$.

${ }^{28}$ Compare Section 4 of the Mecklenburg Declaration of Independence of May 20, 
Convention to get away from the common law by a complete codification of the laws of the state. ${ }^{29}$ The time allotted for this task was rather short, ${ }^{30}$ however, and the inevitable result was a resounding victory for the common law, culminating in the enactment of the following permanent reception statute in 1777 :

[A]ll such Statutes and Parts of Statutes, and such Parts of the Common Law, as were heretofore in Force and Use within this Territory, and all the Acts of the late General Assemblies thereof, or so much of the said Statutes, Common Law, and Acts of Assemblies, as are not destructive of, or repugnant to, or inconsistent with, the Freedom and Independence of this State, and the Form of Government therein established ... are hereby declared to be in full Force within this State, and shall be observed accordingly. ${ }^{31}$

Subject to minor modifications, the same act was reenacted in $1778^{32}$ and remained in force until the $I 837$ Revisal.33 There is some question, however, as to what statutes were then considered to have been "formerly in force." There are four separate indications, individually inconclusive, but collectively strongly persuasive, that after the Revolution the Statute of Frauds was not regarded as being in force in North Carolina. First, in 1784 , the Assembly passed an "Act to regulate the Descent of real Estates, to make Provision for Widows, and to prevent

I775, I R.S. 3-4 (1837): "That as we now acknowledge the existence and control of no law or legal officer, civil or military, within this county, we do hereby ordain and adopt as a rule of life, all, each, and every of our former laws, - wherein nevertheless, the crown of Great Britain never can be considered as holding rights, privileges, immunities or authority therein." It is, of course, not claimed here that doubts as to the authenticity of the Mecklenburg Declaration have been settled; but even if it is an invention, it is an early invention which illustrates the constitutional thinking of the period herein discussed.

${ }^{20}$ An ordinance appointing a committee "to revive [revise?] and consider all such statutes and acts of the Assembly as are or have been in force and use in North Carolina and to prepare such Bills to be passed into laws as may be consistent with the Genius of a Free People, that form of government which we have adopted, and our local situation and to lay the same before the next General Assembly for their approbation" was passed on December 21, I776. 23 N.C.C.R. 987 (1904).

${ }^{30}$ The Convention adjourned on December 23, 1776. 23 N.C.C.R. 1000 (I904). The first Assembly met at New Bern on April 8, 1777. 24 N.C.C.R. I (I905). This left three months for codification.

${ }^{31}$ L. I777 [2d Sess.] c. XIV; 24 N.C.C.R. I13 (I905). The first reception ordinance had previously been extended for one more session: L. I777 [Ist Sess.] c. XXV, id. at 36.

${ }^{32}$ L. 1778, c. V; 24 N.C.C.R. 162 (I905); IREDELL 353.

${ }^{33}$ See I POTTER's ReVisal 356 (I82I); also text infra at note 43 . 
Frauds in the Execution of last Wills and Testaments, ${ }^{34}$ the provisions of which are closely modelled after parallel provisions of the English Statute of Frauds. ${ }^{35}$ If the latter had been regarded as being in force, it might be argued, such a reenactment would not have been necessary. Second, in I792, F. X. Martin published a collection of English statutes in force in North Carolina, ${ }^{36}$ and this collection does not include the Statute of Frauds. Third, in I80I, Judge Taylor of the Superior Court ${ }^{37}$ is reported to have said "that the statute of frauds in England enacts that no creation of trust or declaration of one shall be proved by parol evidence; whence it was to be inferred that before that act such parol declaration was valid; and our law is the same as in England before that statute."38 Lastly, Potter's Revisal (I82I), which contains a list of English statutes that the compilers deemed to be in force in North Carolina, omits the Statute of Frauds. ${ }^{30}$ Almost simultaneously with the receipt of the latter list, the legislature enacted a statute requiring all executory contracts for the sale of land or slaves to be in writing. ${ }^{40}$ Seven years later, it reenacted two of the provisions of Section IV of the English statute. ${ }^{41}$ Again, it can be argued that such reenactment would have been unnecessary if the English Statute of Frauds had been regarded as being in force.

In I 837, "all the statutes of Great Britain heretofore in use in this

${ }^{34}$ L. 1784 , c. XXII; 24 N.C.C.R. 572 (1905); IREDELL 488 .

${ }^{36}$ Compare $\$ \S 14,15$, and 16 of the Act of 1784 with 29 Car. II, c. 3, $\$ \S 22,19$, and 20, respectively. Section 15 of the North Carolina Act, pertaining to nuncupative wills, could almost pass for an identical twin of section 19 of the English statute.

${ }^{36}$ Martin, a Collection of the Statutes of the Parliament of England in Force in THE STATE of NoRTh Carolina (1792), "of which work $i[t]$ may only be remarked that it was utterly unworthy of the talents and industry of the distinguished compiler, omitting many important statutes, always in force, and inserting many others, which never were. ..." These unkind remarks are from Iredell (Jr.) and Battle's preface, $x$ R.S. xii ( 1837 ).

${ }^{37}$ The Superior Court at that time was the highest court in North Carolina. See Battle, History of the Supreme Court, to3 N. C. 341-58 (1889); and Clark, The Supreme Court of North Carolina in I PAPERS OF WALTER CLARK 507-10 (Brooks and Lefler ed. $\times 948$ ), 177 N. C. $6 \times 7,6 \times 9-20$ (1919).

${ }^{38}$ Foy v. Foy, 3 N. C. [2 Haywood] 13 I (Super. Ct., New Bern, $180 x$ ).

${ }^{30}$ I PotreR's Revisal 85-93 (1821). The statute provided that "it shall be the duty of the ... commissioners to enumerate and specify those statutes and parts of statutes of Great Britain which are in force within this state." L. I8I7, c. XVI, LAws of North Carolina ENacted in the Year 1817,17 (1818).

${ }^{40} 2$ POTTER's REvisal $\times 493$ ( $182 \mathrm{r}$ ), now (with substantial amendments) G. S. $\S 22-2$ (1953).

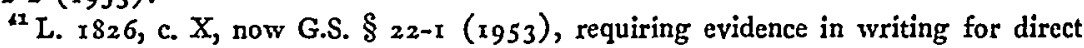
actions against executors and administrators, and requiring specialty contracts to be in writing. 
State" were "declared to be repealed;" 42 and the common law reception clause was rewritten so as to preclude their surreptitious re-entry under the guise of "common law."43 Consequently, there can be no doubt that since I837, the English Statute of Frauds, with the exception of the clauses expressly reenacted, has not been in force in North Carolina.

\section{A Page of Biackstone}

Since the most plausible theory seems to be that the Statute was in force in North Carolina from I7I I until I776, but not from 1776 to I837, and, paradoxically, since the post-I 776 reception statutes purported to revive all statutes which had been in force in the colony, some explanation seems to be required.

Colonial theory with respect to English law seems to have been that statutes enacted at home had to be reenacted in the colonies to be in force there. ${ }^{44}$ It mattered little whether such statutes had been enacted in the mother country before or after the granting of the Charter. That is why the Statute of Frauds, enacted twelve years after the grant of the second Charter ( 1665 ), was specifically reenacted both in North and South Carolina, and, it is submitted, received in practice in the former colony. Post-revolutionary theory, however, quite clearly seems to have been that English statutes of a general nature enacted before the settlement of the colony were in force there, while post-settlement acts of Parliament extended to the colonies only if the acts so provided. ${ }^{45}$

${ }^{4}$ I R.S. $52-53(1837)$.

${ }^{43}$ Omitting all reference to statutes, the new reception clause reads:

"[A]11 such parts of the common law, as were heretofore in force and use within this State, or so much of the said common law as is not destructive of, or repugnant to, or inconsistent with, the freedom and independence of this State and the form of government therein established, and which has not been otherwise provided for in whole or in part, not abrogated, repealed, or become obsolete, are hereby declared to be in full force within this State." I R.S. I Io (1837).

The present reception clause is substantially identical with the above. G.S. $\S 4^{-I}$ (I953).

"Thomas Nairne, in his letter of July 28, 1708, op. cit. supra note 13, at 435, stated that "it's a general rule of Law, taken up in this place, that no English Act of Parliament is in force until made so by an Act of this Province." The South Carolina act of 1712 reenacted English statutes passed as late as I709. Grimke, The Public Laws of the State of Soutr-Carolina 26, 97 (1790). The last statute adopted by North Carolina was I I Geo. II, c. 19, $\S \S I_{3}$ and 20 , passed in 1738.23 N.C.C.R. 317 , $[3]_{26}$ (1904).

"The standard authority for this position is the first resolution of a memorandum of the Master of the Rolls, dated August 9, 1722, on an anonymous Privy Council decision, reported in 2 P. Wms. 75, 24 Eng. Rep. 646:

"I[f] there be a new and uninhabited country found out by English subjects, as the law is the birthright of every subject, so, wherever they go, they carry their laws with them, and wherefore such new found country is governed by the 
There is little diffculty in accounting for this sudden change in theory: the post-revolutionary view is a simplified restatement of Blackstone; ${ }^{46}$ and Blackstone was not only very popular in the colonies generally, ${ }^{47}$ but also quite well known to persons playing an important part in the establishment of North Carolina's legal system. ${ }^{48}$ Furthermore, authority other than Blackstone, supporting the same views, was extant at that time ${ }^{49}$ and probably available to some. Since this theory tied in very nicely with anti-English sentiment, ${ }^{50}$ its acceptance was greatly facilitated. So enthusiastically was it accepted that one of its essential elements was overlooked. Blackstone merely purported to state which English statutes, under English law, were applicable to the colonies. He did not attempt, and in light of the rather sparse information on the colonies, ${ }^{51}$ could not, ${ }^{52}$ have attempted to discuss which English

laws of England; though, after such country is inhabited by the English, acts of parliament made in England, without naming the foreign plantations, will not bind them. ..."

See also Martin, a Collection of the Statutes of the Parliament of England in Force in the State of North Carolina III (x792); Haywood, The Duty and Office of Justices of THE Peace $144-45$ (1800) (adopting 1607 as the critical date); $x$ PotTER's Revisal vi ( 1821 ). The compilers of the last work actually recognized that the Act of $17 \times 1$ (there referred to as the Act of 1715 ) did reenact several English statutes passed after 1665 , but they claim that such statutes were abrogated by the Revolution, merged in the declaration of rights, or superseded by laws providing for the same subjects.

48 I BL. CoMm. * $106-*_{109}(1765)$.

${ }^{47}$ Edmund Burke is reported to have said, "I hear that they have sold nearly as many of Blackstone's Commentaries in America, as in England." I STORT, ComMENTARIES ON THE CONSTITUTION OF THE UNITED STATES $153 \mathrm{n}, 2$, at 156 (1833).

${ }^{48}$ See Coates, $A$ Century of Legal Education, 24 N.C.L. REv. 307, 316-17 (1946).

“o The authorities are collected and discussed in SMITH, Appeals to THE PRIVY Council from the american Plantations 467-95 (i950); and Latham, The Law AND THE Commonwealth 5 44-17 (1949). For an early collection see i ChalMERs, Opinions OF EMINENT LaWYers 194-225 (1814).

${ }^{50}$ See MARTIN, op. cit. supra note 45 , at VI: "This publication will at least serve to disseminate the knowledge of a number of laws by which the people of this state are to be governed, until, substituting acts of their own legislature to those their forefathers brought over from Great-Britain, they will shake off this last seeming badge, and mortifying memento, of dependance on her."

${ }^{51}$ William Samuel Johnson of Connecticut, who was then engaged in practice before the Privy Council, made the following entry in his diary on Novennber 27, 1769: "I heard a respectable counsellor at law ask Mr. Jackson gravely in the Hall whether Philadelphia was in the E. or W. Indies and said he had a notion it was upon the coast of Sumatra. Such is their knowledge of America." Cited by SMirm, stipra note 49 , at $473 \mathrm{n}$. 19 .

${ }^{82}$ His own information was not very accurate; he made the curious blunder of stating that the American plantations were principally conquered rather than discovered 
statutes, under colonial law, were applicable to the colonies. The simple fact that Blackstone's rule merely circumscribed the minimum reception of English statute laws, but that beyond this the colonies were free to adopt additional English statutes, seems to have escaped general attention. It may be, however, that the legalistic flavor of the Revolution ${ }^{53}$ entrenched this gloss on Blackstone's view so firmly in the legal minds of the Revolutionary generation that it could no longer be shaken off. ${ }^{54}$

The patently erroneous view that Blackstone's test contained the sole measure for the reception of English statutes in the colonies ${ }^{55}$ was the view of those who are responsible for the enactment of the statutory basis of North Carolina state law and the constitution itself; and their mistakes are binding on future generations, at least so far as positive law is concerned. Since, furthermore, the common law reception acts passed in 1777 and $1778,{ }^{56}$ while referring to statutes formerly in force, were conceived to be constitutive of new law rather than declaratory of old, ${ }^{57}$ they have to be understood as their framers understood them. The result is inescapable: the Statute of Frauds, not having been enacted prior to the grant of the original Charter, was not in effect in North Carolina after 1776 .

\section{SUMmary}

The objective of this study was merely to examine the history of the English Statute of Frauds in the law of North Carolina. As a matter of positive law, it can safely be concluded that all portions of the Statute not reenacted in the Revisal of 1837 or since that time are not now part of the law of North Carolina. All conclusions beyond that are highly doubtful, but it is submitted that a reasonably sound case has been made out for the view that the Statute 29 Car. II, c. 3 was in force from I7II to I776, but not thereafter.

Hans W. BAade

and settled territories. I BL. CoMm. * ro7. This was enough to arouse even Mr. Justice Story's wrath. See I STORY, op. cit. supra note 47 , at $\times 34-39$.

${ }^{53}$ See Edmund Burke's comments quoted in I STORY, op. cit. supra note 47 , at 153 n. 2, at $156-57$.

"Interest in public law was at an all-time high; and as Professor Radin observed in another connection, "public law, as it appeared to historians disdainful or innocent of law in general, was a marvelous thing-not quite law and sufficiently public." Radin, On Legal Scholarship, 46 Y ALE L.J. I 124 , $1 \times 38$ (1939).

${ }^{\circ}$ Patently erroneous because, obviously, both North and South Carolina, by legislative acts, adopted or purported to adopt English statutes enacted after the settlement of the colony. See note 44 supra.

${ }^{50}$ See notes $3 x$ and 32 supra and accompanying text.

"Tee note 28 supra and accompanying text. 